\begin{tabular}{|l} 
JOURNAL OF EMPOWERMENT \\
VOL. 2, No. 1, June 2021, h. 16-32 \\
ISSN 2580-0620 (Print) \\
ISSN 2597-9809 (Online) \\
Available Online at https://jurnal.unsur.ac.id/index.php/JE \\
\hline \hline
\end{tabular}

\title{
REVITALISASI NILAI-NILAI PANCASILA DALAM MEMBENTUK KARAKTER WARGA BINAAN LEMBAGA PEMASYARAKATAN KELAS IIA KARAWANG
}

\author{
REVITALIZING THE VALUES OF PANCASILA IN FORMING CHARACTER \\ KARAWANG CLASS IIA PUBLIC SERVICE INSTITUTION DEVELOPMENT CITIZENS
}

\author{
Lusiana Rahmatiani \\ Universitas Buana Perjuangan Karawang \\ lusiana.rahmatiani@ubpkarawang.ac.id
}

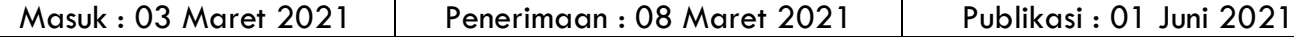

\begin{abstract}
ABSTRAK
Permasalahan sosial muncul akibat adanya ketimpangan dalam faktor kehidupan sosial yang menyebabkan tindak kejahatan, sehingga menyebabkan adanya hukuman bagi seseorang yang telah melakukan perbuatan melawan hukum yang menyebabkan dirinya di hukum di lembaga pemasyarakatan. Tujuan pengabdian masyarakat ini, untuk memberikan sosialisasi akan pentingnya pengetahuan dan pemahaman nilai-nilai Pancasila serta nilai karakter dalam membentuk karakter warga binaan yang sedang menjalankan masa hukuman serta implementasi tridhrama perguruan tinggi. Metode yang digunakan dalam pelaksanaan pengabdian menggunakan metode ceramah. Hasil pengabdian masyarakat berupa adanya upaya untuk menghidupkan kembali, membangkitkan kembali dan mengingatkan kembali nilainilai pancasila sebagai guiding principle dalam kehidupan serta pembentukan karakter para warga binaan agar menjadi bekal untuk kehidupan yang lebih baik dimasa depan setelah lepas dari masa tahanan.
\end{abstract}

Kata Kunci : Karakter; Nilai; Pancasila; Pembinaan; Pemasyarakatan.

\begin{abstract}
Social problems arise due to the imbalance in social life factors that lead to crime, thus leading to penalties for someone who has committed an illegal act which causes him to be punished in a correctional institution. The purpose of this community service is to provide socialization of the importance of knowledge and understanding of the values of Pancasila and character values in shaping the character of the inmates who are serving a sentence and the implementation of the tri dharma of higher education. The method used in the implementation of the service uses the lecture method. The results of community service are in the form of efforts to revive, revive and remind the values of Pancasila as the guiding principle in life and the formation of the character of the inmates so that they become provisions for a better life in the future after being released from detention.
\end{abstract}

Keywords : Character; Values; Pancasila; Coaching; Correctional.

\section{A. PENDAHULUAN}

Permasalahan yang terjadi dewasa ini banyak terdapat pada kehidupan masyarakat. Berbagai ketimpangan kehidupan sangat mencolok terutama dari bidang ekonomi yang menjadi pemicu ketimpangan sosial. Faktor ekonomi menjadi sangat vital dalam kehidupan yang akhirnya menimbulkan berbagai persoalan kehidupan. Antara harapan dan kenyataan menjadi dinamika yang sangat kompleks dalam bidang kehidupan yang menyebabkan munculnya berbagai kekurangan kebutuhan hidup sehari-hari, yang dirasakan oleh lapisan kaum muda maupun lapisan masyakarat kamu tua. Ketimpangan faktor sosial menjadi pemicu munculnya permasalahan sosial yang berkenaan dengan kejahatan diantaranya kasus kejahatan 
seperti kasus pencurian, pembegalan, pembunuhan, pencopetan, penipuan, penggelapan dana dan lain sebagainya yang menyebabkan kerugian untuk orang lain maupun untuk dirinya sendiri karena akhirnya dapat mendekam di penjara.

Setiap insan manusia yang dengan sengaja maupun tidak sengaja melakukan perbuatan yang melawan hukum itu artinya mereka akan masuk sel tahanan atau lapas (lembaga pemasyarakatan). Irawan et al., (2019) menjelaskan bahwa lembaga pemasyarakatan (lapas) merupakan suatu lembaga naungan pemerintah yang menangani para tahanan yang disebut dengan narapidana yang terbukti bersalah melalui proses putusan dari pengadilan. Terpidana adalah seseorang yang di pidana berdasarkan putusan pengadilan yang telah memperoleh kekuatan hukum tetap (Undang-Undang No.12 Tahun 1995 Tentang Pemasyarakatan, n.d.) Seseorang yang masuk kedalam lapas sudah barang tentu kehilangan kemerdekaan seutuhnya, namun narapidana tentunya masih mempunyai hak-hak narapidana yang dilindungi oleh hukum namun kemerdekaannya tidaklah sama dengan insan lainnya yang bisa menjalankan kemerdekaannya diluar tembok pembatas.

Dalam sistem lembaga pemasyarakatan memiliki asumsi bahwasanya warga binaan pemasyarakatan (WBP) merupakan insan manusia yang tidak memiliki perbedaan dengan manusia lainnya maka dalam hal disengaja maupun tidak disengaja dapat melakukan suatu kesalahan yang menyebabkan dirinya dapat dikenakan sanksi pidana, sehingga warga binaan tidak harus dikucilkan sebagai manusia yang sangat berdosa. Narapidana merupakan seorang individu yang terbukti bersalah dengan telah melakukan tindak pidana dan kemudian dijatuhi hukuman pidana oleh pengadilan (Fatimah, Zainul Akhyar, 2015). Sejalan dengan Sujatno, 2008 mengatakan adanya faktor-faktor yang dapat mendorong seseorang melakukan tindakan yang bertentangan dengan agama, hukum, norma susila maupun nilai sosial lainnya yang dapat menyebabkan seseorang akhirnya menyandang status narapidana atau sekarang lebih dikenal dengan WBP.

Pada dasarnya para WBP tetap memiliki perlindungan haknya asasi manusia di mana ada parameter untuk melindungi hak asasi manusia (HAM) warga binaan yang tertuang ke dalam Pasal 71-72 Undang-Undang No. 39 Tahun 1999 Mengenai Hak Asasi Manusia, yang menyatakan pada Pasal (71) bahwasannya pemerintah wajib dan memiliki tanggung jawab untuk menghormati, melindungi, menegakkan, dan juga memajukan hak asasi manusia yang dimana diatur dalam undang-undang ini. Adapun pada asal (72) di mana adanya kewajiban dan juga tanggung jawab dari pemerintah sebagaimana yang dimaksud dalam Pasal 71, meliputi semua langkah implementasi yang efektif dalam bidang hukum, politik, ekonomi, sosial, budaya pertahanan keamanan negara, dan bidang lainnya, oleh sebab itu dirasa penting untuk mengadakan pengabdian pada masyarakat yang dilakukan di dalam lapas untuk merevitalisasi nilai-nilai pancasila dalam membentuk karakter para WBP. Rahmatiani (2017), menjelaskan bahwa pentingnya nilai karakter menjadi salah satu aspek penting yang harus menjelma dalam setiap aktivitas manusia, sebagai paradigma pembangunan nasional. Nilai karakter harus ditanamkan semenjak dini dan juga adanya pembentukan dari suatu pembiasaan diri dalam melaksanakan nilai-nilai pancasila untuk mencerminkan nilai karakter dalam kehidupan tanpa paksaan dan disadari secara perlahan dalam membentuk karakter baik. Mengacu pada permasalahan yang diajukan untuk dipecahkan, maka tujuan pada kegiatan pengabdian pada masyarakat yang dilakukan di dalam lapas ini yaitu: 1) Mengadakan sosialisasi dengan materi pentingnya pengetahuan nilai-nilai Pancasila untuk kepada para warga binaan dalam membentuk karakter baik warga binaan; 2) Menghidupkan kembali, membangkitkan kembali dan mengingatkan kembali nilainilai Pancasila sebagai guiding principle kepada para warga binaan; 3) Memberikan 
pembelajaran pengetahuan mengenai nilai-nilai Pancasila, nilai karakter baik; 4) Implementasi Tri Dharma Perguruan Tinggi.

\section{B. METODE}

Metode yang dilakukan dalam kegiatan ini merupakan metode ceramah sosialisasi dalam pemberian dan penanaman pemahaman tentang pentingnya nilai-nilai Pancasila dan nilai karakter bangsa agar dapat merangsang motivasi warga binaan untuk memiliki karakter baik dengan pengetahuan yang dimiliki. Metode ceramah merupakan sebuah metode dengan bentuk interaksi melalui penerangan penuturan lisan dari guru kepada peserta didik (Sagala, 2009). Dimana pelaksanaan untuk metode ceramah yaitu berusaha menjelaskan uraiannya maksud dan tujuan kepada audiensi dengan secara centered learning. Sejalan dengan Sanjaya (2010), mengungkapkan bahwa metode ceramah sebagai salah satu cara penyajian pelajaran untuk mentransferkan ilmu pengetahuan melalui penuturan secara lisan ataupun sebuah penjelasan langsung kepada kelompok/audiensi.

Gambar 2. Skema Alur Pelaksanaan Kegiatan Pengabdian

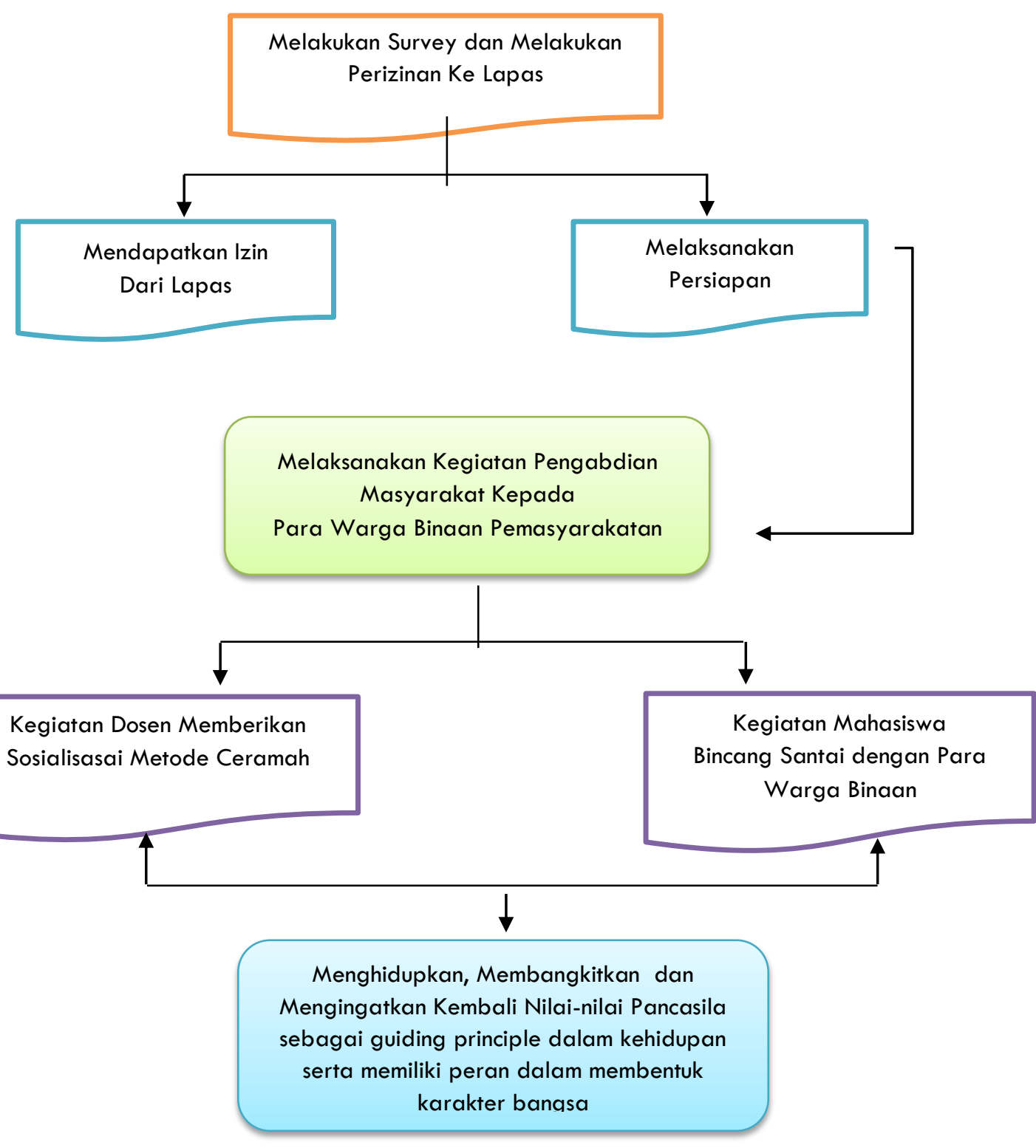




\section{HASIL ATAU PEMBAHASAN}

\section{Landasan Terori}

Lembaga Pemasyarakatan merupakan tempat atau sarana yang disediakan oleh pemerintah Republik Indonesia untuk memberikan pelayanan kepada warga binaan pemasayarakatan. Lembaga Pemasyarakatan Kelas IIA Karawang dibangun pada tanggal 14 Maret 1981 dengan daya tamping (kapasitas) 590 (Lima ratus sembilan puluh) orang WBP dan tahanan dioperasikan pada 14 Juli 1987. Lembaga Pemasyarakatan Kelas IIA Karawang terletak di Desa Warung Bambu, Kecamatan Karawang Timur, Kabupaten Karawang. Berdasarkan Keputusan Mentri Kehakiman Republik Indonesia No: M.01.PR.07.03 Tahun 1985 Tentang Organisasi Dan Tata Kerja Lembaga Pemasyarakatan, maka Lembaga Pemasyarakatan Kelas IIA Karawang mempunyai tugas melaksanakan pemasyarakatan yang meliputi :

a. Melaksanakan Pembinaan Narapidana dan anak didik;

b. Memberikan Bimbingan Mempersiapkan sarana dan mengolah hasil kerja;

c. Bimbingan sosial kerohanian narapidana dan anak didik;

d. Melakukan pemeliharaan keamanan dan tata tertib lembaga pemasyarakatan

e. Melakukan tata usaha.

Lembaga pemasyarakatan para narapidana mendapatkan suatu cara binaan dengan adanya usaha rehabilitasi dan reintegrasi sosial warga binaan pemasyarakatan. Adapun tujuan lapas kelas IIA Karawang sebagai berikut:

a. Membentuk warga binaan pemasyarakatan agar menjadi manusia seutuhnya, menyadari kesalahan, memperbaiki diri dan tidak mengulangi tindakan pidana sehingga dapat diterima kembali oleh lingkungan masyarakat, dapat aktif berperan dalam membangun pembangunan dan dapat hidup secara wajar sebagai warga yang baik dan bertanggungjawab;

b. Memberikan jaminan perlindungan hak asasi tahanan dalam rangka memperlancar proses penyidikan, penuntutan dan pemeriksaan di sidang pengadilan;

c. Menjalin kerjasama dengan semua stake holder dalam rangka melaksanakan pembinaan terhadap warga binaan pemasyarakatan dan pelaksanaan tahanan.

Kegiatan pengabdian pada masyarakat yang dilaksanakan pada bulan Maret 2020 sebelum adanya edaran untuk WFH (Work From Home). Pengabdian masyarakat ini dilaksanakan secara langsung dengan menggunakan metode konvensional atau metode ceramah dan sosialisasi nilai-nilai Pancasila kepada para narapidana atau warga binaan pemasyarakatan dengan sasaran Bapak/lbu, saudara/saudari para warga binaan pemasyarakatan berbagai kasus tindak pidana yang dilaksanakan di Lapas kelas IIA Karawang.

\section{a. Karakter}

Karakter merupakan cerminan dari kepribadian seorang manusia yang terbentuk melalui proses internalisasi dari nilai-nilai kebajikan yang dapat digunakan serta dipercayai mampu untuk menjadi sebuah acuan dalam bersikap, melakukan sebuah tindakan dengan berpikir secara logis dan kritis sehingga dapat menimbulkan nilai, norma dan moral yang tercermin dalam kehidupan masyarakat seperti nilai dalam diri seorang manusia yakni, jujur, hormat, sopan santu, berani bertindak, dapat dipercaya dan bertanggung jawab. Di mana dapat dikatakan bahwasannya karakter merupakan sebuah cerminan manusia yang tercermin pada watak, kepribadian, ahlak ataupun tabiat diri (L. Rahmatiani, 2017).

Membentuk karakter seorang manusia tidak lepas dari pola asuh orang tua yang sangat karakter adalah suatu sifat yang ada dalam diri seseorang yang terbentuk atau masih bisa dibentuk dalam pergaulan sehari-hari. Pola asuh orang tua sangatlah 
berpengaruh terhadap karakter anaknya karena apabila orang tua salah dalam mendidik anaknya maka anaknya belum tentu bisa berprilaku dengan baik (Martini, 2018).

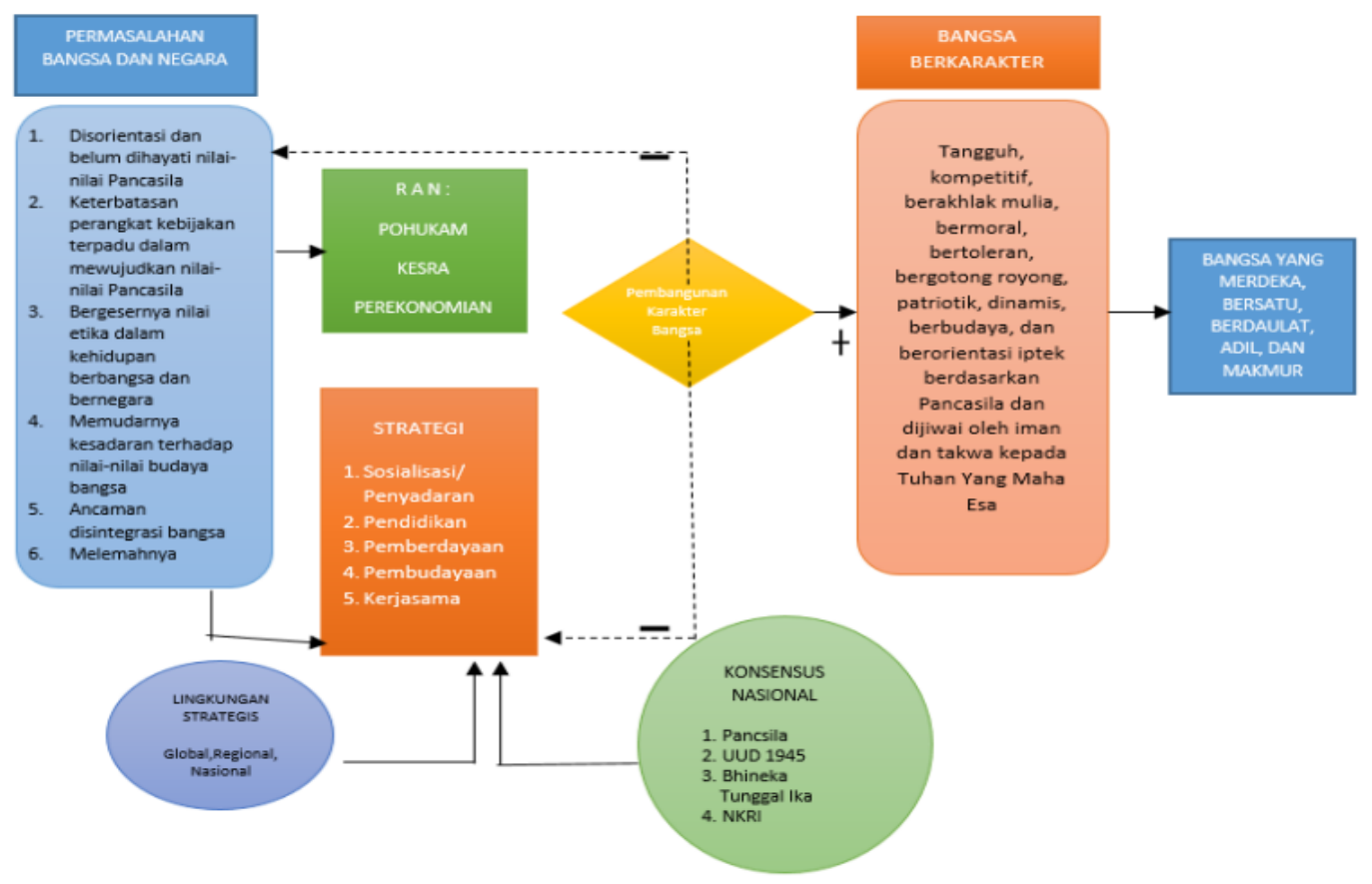

Gambar 1. Kerangka Kebijakan Nasional Pembangunan Bangsa dan Karakter (Menkokesra : 2010 dalam Akbal, 2016)

Pada prinsipnya para warga binaan tetaplah memiliki hak sebagai warga negara yang senantiasa dapat ikut andil dalam pembangunan karakter bangsa (national character building) menjadi penting dalam pembangunan bangsa, sebagaimana karakter menjadi pilar dan jati diri sebuah bangsa untuk tetap tumuh dan berkembang sehingga tercipta masyarakat yang baik dan cerdas (smart and good a citizen) yang mampu bersaing di era kompetitif dan mampu beradaptasi dengan adanya pengaruh globalisasi dalam berbagai bidang kehidupan (Akbal, 2016).

Generasi muda yang memiliki karakter baik dan cukup mempuni dalam dirinya akan mampu untuk beradaptasi dalam pergaulan sosial kehidupan yang dibutuhkan. Karakter bangsa dapat menjelma pada personal diri dengan mempunyai sikap dan suatu tindakan yang demokratis, mampu bertanggung jawab serta mampu berpikir logis dan kritis dalam menentukan suatu perbuatan, termasuk menentukan perbuatan itu dapat merugikan diri sendiri ataupun menentukan perbuatan yang melanggar hukum yang tentunya memiliki sanksi hukuman untuk dirinya. Interaksi seorang warga negara dengan lingkungan dapat menentukan arah karakter bangsa.

Nasib sebuah bangsa ditentukan oleh bangsanya sendiri, bukan ditentukan oleh bangsa lain, sehingga perlunya mempersiapkan generasi muda bangsa untuk masa depan sangat ditentukan oleh eksistensi suatu negara dalam pembentukan warga negara yang memiliki karakter, perubahan kearah yang diinginkan dan sesuai dengan cita-cita bangsa yaitu warga negara yang memiliki karakter Pancasila yang memiliki keunggulan watak yang dinamis serta mampu kompetitif dengan tetap menggunakan nilai-nilai pancasila sebagai way of life (L. Rahmatiani, 2020). Sejalan dengan hal tersebut Mukhadis, (2013) mengakatan bahwa karakter bangsa Indonesia yang dibutuhkan 
pada era globalisasi seperti sekarang yakni karakter yang mampu untuk bekerjasama dalam atmosfer persaingan, mampu untuk bersaing dan menerima pendapat dengan baik, memiliki etos kerja yang tinggi, mampu dalam manajerial waktu, mempunyai gaya komunikasi yang bijak, memiliki keahlian dalam menguasai teknologi serta memiliki sikap yang baik.

Karakter baik ataupun karakter mulia yang tercermin dalam setiap individu dapat ditandai dengan adanya perbuatan baik yang dapat diimplementasikan oleh dirinya secara sadar dan penuh tanggung jawab yang tidak melanggar norma atau kaidahkaidah yang ada dalam sosio masyarakat, individu yang memiliki suatu kesadaran diri untuk mampu melakukan perbuatan baik, sehingga perwujudannya dapat dirasakan dalam kehidupan sehari-hari dalam beraktifitas dengan adanya nilai-nilai baik dalam bersikap, dapat dipercapya dan memiliki tanggungjawab, amanah, memiliki kepercayaan diri, dapat menentukan sikap yang dibarengi oleh pemikiran yang logis dan kritis, serta rendah hati dan juga berani mengabil keputusan dan menentukan sikap untuk dapat menepati suatu janji atau perbuatannya (L. Rahmatiani, 2017).

\section{b. Nilai}

Nilai memiliki sifat yang absolut, tidak dapat dirubah maupun berubah dengan sendirinya dan juga tidak dapat bersifat secara subjektif. Nilai dapat di amati secara langsung dengan intuisi manusia yang hadir dengan melibatkan pikiran dan juga sebuah pertimbangan yang logis. Nilai dapat digunakan sebagai prinsip hidup bagi kita dalam melakukan penilaian terhadap perilaku setiap manusia yang bersifat manusiawi baik ataupun benar dari perbuatan manusia itu sendiri. Nilai objektif yang muncul dari adanya moralitas yang didasarkan pada sebuah perbuatan manusia (Bertens, 1983).

Nilai menjadi suatu realitas yang abstrak, yang menjadi pendorong dan sebagai prinsip dalam diri untuk pedoman hidup. Nilai memiliki kedudukan yang sangat penting dalam kehidupan manusia. Nilai dijunjung tinggi oleh setiap insan manusia dan juga bagi warga masyarakat ataupun kelompok-kelompok masyarakat berdasarkan sosiobudaya masing-masing, maka dari itu sebuah nilai yang tersemat pada setiap diri manusia sangat dijaga dan menjadi suatu pertaruhan. Nilai suatu realitas yang sangat terbuka dan tidak berada sendirian, dimana nilai saling keterkaitan dengan kehidupan yang ada pada diri manusia itu sendiri maupun yang berkaitan dengan sosiomasyarakat. Nilai yang dimiliki oleh seseorang sudah ditanamkan oleh keluarga dan terbiasakan oleh lingkungan sosial (Jirzanah, 2016).

Penerapan nilai dalam kehidupan seseorang tidak akan terlepas pada suatu lingkaran noral dan etika sebagai salah satu dasar dalam menentukan persoalan dari teori nilai Dalam pandangan seorang manusia sebagai monodualis dapat dilihat pada hakikat manusia itu sendiri yang pada prinsipnya manusia dibagi kedalam tiga bagian, yaitu:

1) Hakikat kodrat manusia; memiliki jiwa dan raga, merupakan sebuah kesatuan yang tidak dapat untuk dipisahkan maupun dipertukarkan, tetapi dapat terpisah yang disesuaikan pada fungsinya;

2) Sifat kodrati manusia; yang berkaitan dengan aktivitas sebagai individu maupun dalam kehidupan sosial, dalam menentukan sesuatu harus dengan seimbang dan menghindari perilaku menyimpang yang dapat merugikan dirinya sendiri;

3) Kedudukan kodrat manusia; yaitu sebagai makhluk ciptaan tuhan yang mampu untuk berdiri diatas kaki sendiri dengan kemampuan untuk dapat menentukan kebenaran maupun suatu keburukan dari penilaiannya (Qiqi Yuliati Zakiyah \& A. Rusdiana, 2014).

Manusia pada hakikatnya memiliki nilai-nilai kemanusiaan yang menjadi sifat bawaan bersifat kodrati. Pengembangan nilai kemanusiaan berdasarkan pada prinsip humanitas sebagai kodrat manusia dalam mencapai keutuhan atas harkat dan martabat yang 
tercermin pada kemampuan berpikir logis dan aktualisasi moral dalam kehidupanya (Jirzanah, 2016). Dapat disimpulkan bahwasannya nilai memiliki esensi yang sangat erat dengan kehidupan seorang manusia, dimana nilai sangat berkaitan dengan baik buruknya seorang manusia dengan penilaian yang sangat abstrak tetapi dapat diyakini kebenarannya dari suatu seleksi perilaku manusia dalam berkehidupan.

\section{c. Pancasila}

Pancasila menjadi dasar negara Indonesia karena bersumber dan berakar dari nilainilai dasar yang ada di nusantara yang terkristalisasi pada beragam kultur budaya Indonesia. Pancasila menjadi pandangan hidup bangsa (way of life) bangsa Indonesia yang melahirkan suatu tatanan sosial yang terstruktur pada bangsa Indonesia yang mengakui dan menghormati adanya harkat dan martabat manusia. Pancasila sebagai dasar negara mengakui dan melaksanakan jaminan atas hak asasi manusia, adanya penegakan dibidang hukum, sebagai intrument dalam mentaati peraturan, oleh sebab itu pancasila dapat diposisikan sebagai idelogi terbuka. Pancasila sebagai dasar negara dapat menyesuaikan pada tuntunan perkembangan jaman juga bersifat dinamis yang diharapkan bahwa nilai-nilai Pancasila yang dibelajarkan bukan hanya sekedar Pancasila sebagai teori semata tetapi Pancasila sebagai wujud dalam suatu tindak perilaku hidup bangsa indonesia yang terwujud pada perilaku masyarakat Indonesia (Riyanto, 2007).

Pancasila sebagai ideologi bangsa, pandangan hidup bangsa dan sebagai dasar negara yang menjadi pedoman bagi bangsa Indonesia pada tatanan kehidupan masyarakat, berbangsa dan bernegara sehingga mampu akan mewujudkan cita-cita bangsa. Pancasila harus menjadi landasan dalam penyelenggaraan negara, serta menjadi pedoman dalam pembentukan peraturan perundang-undangan, dimana negara dalam menentukan undang-undang dan atau melaksanakan perundangundangan harus dapat mencerminkan nilai-nilai luhur Pancasila, nilai luhur Pancasila bersumber dari budaya bangsa Indonesia sendiri (Octavian, 2018).

Upaya dalam menuangkan contoh nilai-nilai Pancasila yang dilakukan oleh narasumber dengan menggunakan bahasa yang dapat dipahami oleh warga binaan, dengan menggunakan ungkapan contoh kongkrit yang dapat dijabarkan kepada para warga binaan agar mereka mampu untuk mendapatkan gambaran nyata dalam berkehidupan selama di lapas dan setelah keluar dari lapas. Adapun contoh dari nilai sila kesatu yaitu Ketuhanan; sesama makhluk hidup harus mampu untuk hidup saling menghargai, menghormati juga memahami sehingga munculnya rasa toleransi yang tinggi antar pemeluk agama yang berbeda dengan keleluasaan untuk adanya kebebasan dalam menjalankan ibadah sesuai kepercayaan-Nya. Contoh nilai dari sila kedua yaitu Kemanusiaan; adanya pengahargaan dan pengakuan pada harkat dan martabat setiap manusia tanpa mengabaikan hak asasi manusia yang dimiliki setiap indvidu, mampu menumbuhkan dalam diri rasa tenggang rasa dan menghargai agar tidak terjadi suatu perbuatan yang semena-mena terhadap oranglain. Contoh dari nilai sila ketiga yaitu Persatuan; memiliki dan menumbuhkannya rasa cinta tanah air, cinta terhadap persatuan bangsa, memiliki dan menumbuhkan rasa rela berkorban demi kepentingan bangsa dan negaranya, adanya pengakuan keragaman suku, budaya, adat, bahasa sekaligus mendorong ke arah pembinaan persatuan dan kesatuan bangsa Indonesia. Contoh nilai yang keempat, yaitu Kerakyatan; dalam setiap mengambil suatu keputusan sangat mengutamakan adanya musyawarah, juga mengutamakan kepentingan negara demi kepentingan bangsa dan rakyatnya daripada kepentingan pribadi ataupun kepentingan golongan. Contoh nilai sila kelima, yaitu Keadilan: dapat bersikap adil walaupun adil tidak harus sama rata sama rasa karena kebutuhan 
seseorang kebutuhan setiap daerah memiliki perbedaan dan kebutuhannya yang disesuaikan dengan kebutuhannya, mampu untuk memberikan pertolongan kepada orang lain tanpa pamrih atau balasan, memiliki rasa cinta kepada tanah air akan kemajuan dan pembangunan nasional untuk kepentingan bersama baik dari segi material maupun spiritual (Danniarti, 2017).

Mengimplementasikan nilai-nilai Pancasila pada setiap bidang kehidupan bermasyarakat sangat diperlukan agar terwujud secara nyata nilai toleransi, saling menghargai, saling memahami, tenggang rasa, gotong royong, sopan santun dalam kehidupan masyarakat indonesia yang tentunya dapat terimplementasikan oleh para warga binaan agar mampu hidup bersanding dan berdampingan dengan masyarakat luas saat mereka terbebas dari lembaga pemasyarakatan.

\section{d. Pembinaan}

Pembinaan merupakan sebuah upaya adanya pembentukan kembali terhadap para warga binaan dengan maksud dan tujuan untuk menjadikan manusia kembali suci, bersih dan lebih baik dari kehidupan sebelumnya dimasa lalu yang pernah ia perbuat. Pembinaan di dalam lembaga pemasyarakatan diatur pada pasal 5 sampai pasal 9 Undang-Undang No.12 Tahun 1995 Tentang Pemasyarakatan, yang mengatur mengenai pembinaan warga binaan pemasyarakatan dilaksanakan dalam lembaga pemasyarakatan dan mendapatkan pembimbingan warga binaan pemasyarakatan di lakukan di BAPAS (balai pemasyarakatan).

Hamzah, (1983) mengungkapkan tujuan dilakukannya pembinaan bagi para warga binaan memiliki keterkaitan dengan tujuan pemidanaan yang diatur pada tujuan penjatuhan pidana, yaitu:

a. Menegakkan norma hukum demi pengayoman kepada masyarakat agar adanya pencegahan suatu tindak pidana yang dilakukan oleh masyarakat;

b. Melakukan perbaikan terhadap warga binaan untuk menjadikan seseorang yang lebih baik dari sebelumnya dan berguna untuk hidup berdampingan dengan masyarakat;

c. Adanya pemulihan keseimbangan dan memunculkan rasa damai dalam masyarakat karena adanya konflik yang ditimbulkan oleh pelaku tindak pidana;

d. Membersihkan rasa bersalah yang melekat pada warga binaan agar dapat hidup dengan pribadi yang baru.

Pengarahan pada kegiatan pembinaan lebih diarahkan pada upaya penyatuan warga binaan dengan kehidupan sebenarnya di dalam masyarakat, dengan metode Community Based Correction adanya kemungkinan warga binaan dalam lembaga pemasyarakatan dapat dibina hubungannya menjadi lebih baik dengan mengembangkan hubungan baru kearah yang positif (Tholib, 2015 dalam Saputra, 2020). Community Based Correction merupakan suatu program pembinaan bagi para warga binaan yang sedang menjalani masa tahanan dengan adanya pemberian kesempatan untuk dapat bergabung ke tengah kehidupan masyarakat dengan adanya pengawasan tertentu, sehingga tingkat keberhasilan dari pembinaan metode Community Based Correction ini dapat ditentukan oleh banyaknya bariabel yang meliputi warga binaan, peranan aktif masyarakat dan juga petugas lapas. Community Based Corection atau dikenal dengan pembinaan yang juga melibatkan masyarakat dengan pendekatan kekeluargaan dan pengamanan yang minim tanpa adanya jeruji besi ataupun tembok pemisah ruang dan waktu (Hamia, 2014).

Dalam konteks lembaga pemasyarakatan, pembinaan menjadi salah satu sistem terpadu pada warga binaan yang memiliki keterkaitan pada suatu tujuan. Adapun komponen tersebut meliputi berbagai pihak yang terlibat dalam proses pembinaan para warga binaan, diantaranya warga binaan, petugas LAPAS (lembaga pemasyarakatan, serta 
masyarakat itu sendiri yang akhirnya mau untuk menerima kembali kehadiran warga binaan dalam lingkungan masyarakatnya (Saputra, 2020). Jadi dapat disimpulkan bahwasannya pembinaan dilakukan kepada warga binaan dengan maksud untuk mempersiapkan kembali personality (diri) mantan napi bekas warga binaan yang memiliki kepribadian baik dan terpuji serta tidak melakukan perbuatan yang dapat mengancam mereka kembali ke jeruji besi atau tindakan melawan hukum.

\section{e. Pemasyarakatan}

Lapas atau lembaga pemasyarakatan merupakan tempat untuk para warga binaan dalam melaksanakan pembinaan sebagai warga binaan yang dinyatakan dalam proses pengadilan dengan penjatuhan vonis pidana dan dinyatakan bersalah sehingga pelaku harus masuk dalam sel besi. Pembinaan kepada warga binaan menjadi bagian yang sangat penting dan tidak dapat terpisahkan dari sistem pemasyarakatan. Pemasyarakatan berada di bawah Induk organisasi dan tanggungjawab Kementerian Hukum dan HAM melalui Direktorat Jenderal Pemasyarakatan (Situmorang, 2019).

Warga binaan mendapatkan perlakuan khusus dalam suatu tempat yang dikenal dengan lapas (lembaga pemasyarakatan) yang memiliki fungsi untuk melakukan pembinaan kepada para warga binaan. Lembaga pemasyarakatan memiliki tujuan untuk memberikan suatu upaya penjaminan hak serta pembinaan untuk para narapidana atau sekarang lebih dikenal dengan warga binaan dengan menjamin hakhak terhadap para warga binaan dapat terpenuhi (Rahmatiani, L \& Asmara.,A.,S 2020). Senada dengan Romli Atmasasmita, yang mengungkapkan bahwa Pemasyarakatan merupakan suatu proses memasyarakatkan kembali warga binaan agar dapat menjadi warga negara yang baik, berguna bagi nusa dan bangsa yang dapat diterima kembali dilingkungan masyarakat yang telah melakukan resosialisasi dalam lembaga pemasyarakatan (Atmasasmita, 1982).

Lembaga pemasyarakatan memiliki fungsi untuk mengembalikan warga binaan kepada lingkungan masyarakat untuk dapat hidup dan berbaur kembali dengan sehat dan bebas seperti warga negara pada umumnya yang memiliki peran dalam pembangunan nasional, sehingga peranan lembaga pemasyarakatan membina, membimbing serta melindungi hak-hak warga binaan selama dalam masa tahanan (Saputra, 2020).

\section{Tahap persiapan}

Pada tahap ini dilakukan dengan melakukan survey lokasi serta perizinan terlebih dahulu ke lapas kelas IIA Karawang. Kegiatan pengabdian ini dilaksanakan di aula lapas kelas IIA karawang. Pelaksanaan pengabdian dilaksanakan pada bulan Maret 2020 sebelum adanya edaran dari pemerintah setempat akan WFH (Work From Home).

\section{Tahap pelaksanaan}

Pelaksanaan kegiatan pengabdian pada masyarakat tidak hanya sekedar dilakukan oleh dosen, diikutsertakan mahasiswa agar para mahasiswa dapat langsung bersinggungan dengan insan manusia yang mendapatkan hukuman dikarenakan melanggar perbuatan hukum. Pada kegiatan pengabdian ini dilakukan secara langsung masih dengan tatap muka dikarenakan belum adanya himbauan dari pemerintah daerah dan dari kampus untuk WFH (Work From Home) dikarenakan kasus covid-19 ketika itu masih belum dipastikan masuk ke Indonesia dengan data dan fakta yang mendukung, sehingga kegiatan sosialisasi kepada para warga binaan pemasyarakatan masih dilakukan secara konvensional tatap muka dengan menggunakan metode ceramah dengan tujuan untuk mensosialisaikan dan menghidupkan kembali pengetahuan 
dan pemahaman mengenai nilai-nilai pancasila, nilai-nilai karakter baik, dan kegiatan implementasi nilai pancasila dalam membentuk nilai karakter para warga binaaan dengan menggunakan metode ceramah yang dapat merubah mindset pengetahuan para warga binaan.

Pelaksanaan pengabdian kepada para warga binaan pemasyarakatan masih dilakukan dengan metode konvensional yaitu menggunakan metode ceramah semata, sehingga masih adanya kesan center learning dalam mentransfer ilmu pengetahuan kepada para warga binaan yang dilakukan dalam pengabdian ini dari dosen sebagai narasumber, sehingga menimbulkan suatu rangsangan yang muncul dari para warga binaan pada sesi tanya-jawab, sebelumnya pemateri juga memberikan rangsangan diawal dengan apersepsi untuk memancing pengetahuan yang dimiliki para warga binaan terhadap pemahamannya mengenai nilai pancalisa, nilai karakter, pentingnya nilai pancasila untuk kehidupan, apa itu nilai-nilai pancasila yang seharusnya diimplementasikan dalam keseharian, rangsangan tersebut dilakukan di awal sebelum mulainya pemberian materi untuk para warga binaan.

Pada tahap pelaksaan ini kegiatan dilaksanakan dalam satu hari kerja, dengan beberapa kegiatan:

a. Kegiatan pertama memberikan sosialisasi pemahaman mengenai nilai-nilai Pancasila;

b. Kegiatan kedua memberikan sosialisasi pemahaman mengenai nilai-nilai karakter bangsa;

c. kegiatan ketiga ini mahasiswa berbaur dengan para warga binaan untuk ikut membantu dengan bincang santai untuk memberikan pemahaman pengetahuan kepada para warga binaan mengenai pentingnya implemetasi nilai Pancasila dalam kehidupan sehari-hari dalam membentuk karakter baik agar terciptanya insan manusia yang memiliki nilai, menjalankan norma moral dalam kehidupan sosio masyarakat.

Perubahan pengetahuan dari warga binaan pemasyarakatan mengenai nilai-nilai pancasila belum dapat terlihat perubahan secara signifikan dikarenakan tidak dilakukan uji efektifitas seperti pre test dan post test secara tertulis namun hanya dilakukan secara lisan tanya jawab awal dan akhir setelah pelaksanaan penyajian materi yang dilaksanakan oleh dosen.

Pengabdian ini dapat juga dikatakan sedikit banyaknya merubah pengetahuan mengenai nilai pancasila sebagai guiding principle yang dapat terlihat ketika dilaksanakannya bincang santai dengan mahasiswa yang dicobakan untuk berbaur dengan para warga binaan untuk mengulas materi yang disajikan oleh dosen kedalam kegiatan terbuka tanya jawab mengenai nilai pancasila dan pemahaman nilai karakter bangsa. Kegiatan bincang santai ini dilakukan pertanyaan secara acak oleh mahasiswa kepada warga binaan tanpa menggunakan pertanyaan baku yang dicatat terlebih dahulu dikarenakan menurut pemaparan dari Kasubsi Bimkemaswat para warga binaan lebih senang untuk berkomunikasi dengan santai tanpa menggunakan pertanyaan tertulis yang sifatnya baku dan kaku, yang tentunya bincang santai masih berkenaan dengan materi yang disampaikan oleh dosen.

Menurut keterangan dari para mahasiswa, para warga binaan mampu menyimak dengan baik penuturan materi dari dosen sehingga ketika mahasiswa mencoba untuk bincang santai, memberikan rangsangan kepada para warga binaan dengan pertanyaan-pertanyaan seputaran pemahaman nilai pancasila serta nilai karakter bangsa, dapat disimpulkan para warga binaan dapat merespon dengan baik pengetahuan umum mengenai nilai pancasila dan nilai karakter yang dibutuhkan oleh bangsa Indonesia. 
Para warga binaan dapat merespon dengan baik ketika narasumber telah selesai memberikan materi, terlihat dengan adanya antusias interaksi yang muncul dari para warga binaan untuk melakukan tanya jawab, sehingga dapat disimpulkan bahwasannya kegiatan pengabdian ini dapat memberikan pengetahuan baru dalam kehidupan mereka selama dalam masa tahanan dan juga memberikan pemahaman secara jelas mengenai nilai-nilai pancasila yang harus diimplementasikan untuk membentuk karakter baik dari para warga binaan dengan harapan dapat merubah tingkah laku ataupun sikap dari warga binaan selama berada di dalam lapas dan juga menjadi bekal untuk mereka hidup bersosialisasi dengan lingkungan masyarakat yang sebenarnya. Harapan utama dalam pengabdian masyarakat kepada para binaan adalah merevitalisasi (menghidupkan kembali) pengetahuan para warga binaan mengenai nilai-nilai pancasila untuk dapat mendukung terbentuknya nilai karakter bangsa yang diharapkan dapat mendukung perwujudan pembangunan karakter bangsa (nation character building).

Dalam pelaksanaan pengabdian masyarakat untuk para warga binaan, harus dilakukan secara berkesinambungan agar dapat terlihat secara jelas perubahan pengetahuan dan pemahaman warga binaan mengenai nilai-nilai pancasila dalam membentuk karakter para warga binaan, dengan melakukan teknik pemberdayaan pengetahuan, penanaman sikap dengan membaur pada program-program pembinaan yang sudah menjadi program dari lapas yang akan dilaksanakan oleh dosen, mahasiswa serta keikutsertaan dari warga binaan dengan pengawasan dari petugas lapas sehingga terciptanya role model dari dosen dan mahasiswa untuk para warga binaan.

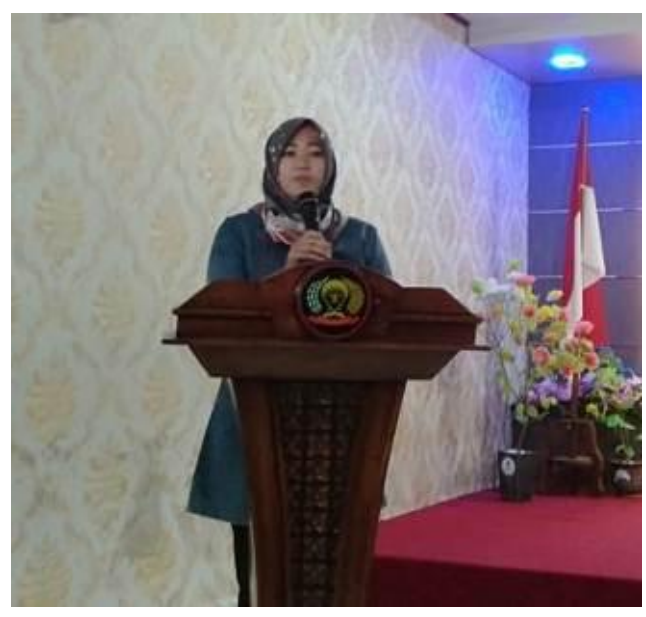

Gambar 2. Sosialisasi Pemberian Materi Oleh Dosen Sebagai Pemateri

Sesuai dengan amanat Undang-Undang No.12 tahun 1995 tentang Pemasyarakatan, di mana Pasal 1 ayat (1) menyatakan bahwa pemasyarakatan merupakan kegiatan untuk melakukan pembinaan Warga Binaan Pemasyarakatan (WBP) berdasarkan sistem kelembagaan dan cara pembinaan yang merupakan bagian akhir dari sistem penindakan dalam tataperadilan pidana. Salah satu atas dasar Undang-Undang tersebut dirasa perlu untuk melakukan pengabdian pada masyarakat dengan sasaran para warga binaan pemasyarakatan karena mereka disana selain mendapatkan pembinaan dari program-program lapas untuk menjadikan hidup mereka lebih baik dimasa yang akan datang, juga diperlukan wawasan dan pengetahuan mengenai nilainilai pancasila yang akan menjadi way of life mereka dalam menjalankan segala aktivitas kehidupannya setelah bebas dari tahanan. 
Pada sesi kegiatan ini berjalan dengan lancar, tercermin dari banyaknya interaksi para warga binaan yang terwujud dari pengajuan pertanyaan, berbagi kisah kehidupan, pengalaman ataupun mengkonfirmasi hal-hal yang sebenarnya telah mereka miliki namun mereka abaikan yang diajukan oleh para warga binaan dalam pemaparan materi mengenai pentingnya kehidupan berbasis nilai-nilai pancasila agar menjadi guiding principles dalam kehidupan mereka sebagai bekas warga binaan agar siap hidup menjadi lebih baik di masa mendatang dan tidak lagi melakukan perbuatan melawan hukum yang tentunya juga melanggar nilai dan norma sosial yang ada di masyarakat yang di mana nilai-norma sosial di masyarakat itu mencerminkan nilai-nilai Pancasila. Yang artinya ketika melanggar hukum maka anda melanggar pula nilai-nilai Pancasila yang menjadi jatidiri bangsa Indonesia.

Di mana dapat disepakati bersama bahwasannya sifat ataupun tingkahlaku seseorang sangat dipengaruhi oleh faktor lingkungan yang membentuk seseorang kedalam suatu kondisi yang membentuk perilaku orang tersebut yang dipegaruhi oleh lingkungannya. Sehingga ketika seseorang memiliki pribadi yang berkarakter apabila dia tumbuh dan berkembang pada lingkungan yang berkarakter begitu sebaliknya, di mana hal ini sangat ditentukan oleh semua pihak diantaranya orang tua, keluarga, sekolah dan kultur masyarakat yang dapat membentuk karakter seseorang (Wening, 2012).

Dapat disimpulkan dalam tingkat pemahaman dan pengetahuan para warga binaan dapat terlihat dari adanya respon yang diberikan oleh dosen melalui stimulus pemberian materi maupun rangsangan pertanyaan, yang dapat disepakati bahwa dengan adanya penghidupan kembali pengetahuan dan pemahaman kepada para warga binaan dapat terlihat dengan jelas dengan munculnya interaksi aktif yang ditimbulkan oleh para warga binaan untuk bertanya, berbagi pengalaman (sharing) ataupun sekedar memastikan kembali apasaja contoh tindakan dalam kehidupan yang pernah mereka alami namun terabaikan dikarenakan minimnya pengetahuan dan pemahaman mengenai nilai way of life dalam menuntun kehidupannya.

Pelaksanaan kegiatan pengabdian pada masyarakat tidak hanya sekedar dilakukan oleh dosen, tetapi juga melibatkan mahasiswa dengan tujuan agar mahasiswa sebagai generasi muda penerus bangsa tidak akan melakukan perbuatan melawan hukum dan memfilter generasi muda untuk melakukan perbuatan yang melanggar norma-norma kehidupan yang bersumber langsung dari para warga binaan pemasyarakatan, hal ini akan merangsang mahasiswa secara langsung agar menghindari perbuatan asusila serta memberikan kesempatan kepada mahasiswa untuk mengeksplor pengetahuannya, pemahamannya kepada para warga binaan untuk langsung berinteraksi memberikan pengetahuan dan pemahaman yang mahasiswa miliki mengenai nilai-nilai pancasila dan nilai karakter bangsa.

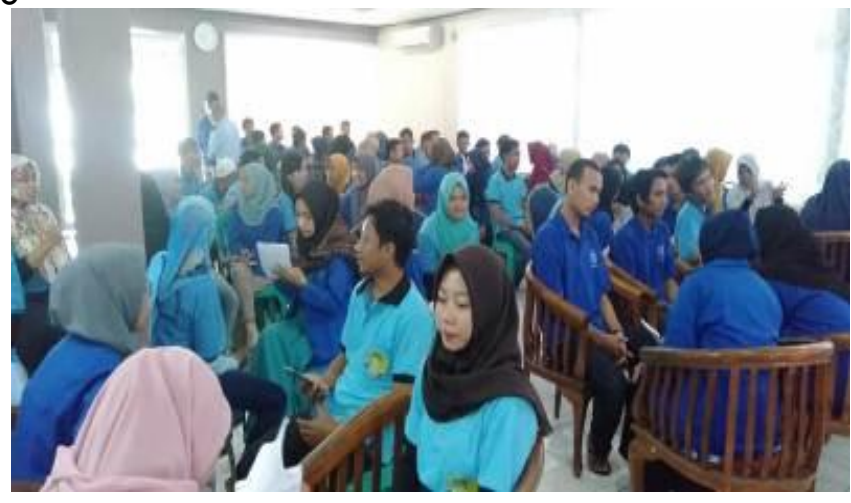

Gambar 3. Kegiatan bincang santai dengan mahasiswa 
Dalam melaksanakan pengabdian pada masyarakat ini tentu ada relevansinya dengan penerapan program pembinaan yang meliputi pembinaan kepribadian, pembinaan kemandirian dan juga pembinaan sosial sebagai bentuk dari upaya lembaga pemasyarakatan kelas IIA Karawang yang dibuat oleh lapas untuk menjadi program lapas dalam melindungi hak-hak narapidana yang juga diharapkan melalui program pembinaan tersebut warga binaan terbentuk watak dan kepribadiannya. Adapun program pembinaan yang ada pada lembaga pemasyarakatan kelas IIA Karawang meliputi perlindungan hak-hak warga binaan, diantaranya:

a. Program pembinaan bimbingan kemasyarakatan;

b. Program pembinaan kepribadian;

c. Program pembinaan olahraga;

d. Program pembinaan kesenian;

e. Program bantuan hukum;

f. Program pelayanan Kesehatan;

g. Program perawatan WBP;

h. Program pembinaan pelatihan keterampilan.

Dengan adanya kegiatan pengabdian kepada para warga binaan pemasyarakatan sangat memiliki dampak yang kuat dalam aspek psikologis mereka, dikarenakan selama menjadi tahanan mereka mencari jatidiri untuk dirinya dan dengan adanya kegiatan pengabdian di lapas ini harapannya adalah dapat membantu para warga binaan pemasyarakatan untuk mampu hidup menjadi lebih baik, memiliki pemahaman mengenai nilai-nilai pancasila dalam kehidupannya dan dalam kehidupan keseharian dapat mampu di implementasikan secara nyata nilai-nilai pancasila yang dalam membentuk nilai karakter kepada para warga binaan masyarakat.

Pengabdian yang melibatkan mahasiswa sangat penting dilaksanakan karena untuk memberikan contoh kehidupan kedepannya kepada para mahasiswa. Adanya suatu upaya yang dapat dibangun oleh semua elemen terkait dalam menyodorkan sebuah solusi untuk merubah pola pikir dan pola sikap masyarakat agar dapat membantu menyehatkan masyarakat dengan kebijakan sosial yang digali dan disesuaikan dengan potensi yang ada pada masyarakat itu sendiri untuk membantu memperbaiki akhlakul kharimah, sifat, karakter untuk menjadi insan manusia yang lebih baik (Amalia, 2017). Aspek yang sangat penting dalam sebuah bangsa salah satunya adalah nilai karakter yang harus menjelma dalam setiap aktivitas manusia dalam kehidupan sehari-hari, nilai karakter yang dimiliki manusia mampu menjadi landasan dalam berorientasi pada program-program pembinaan yang ada dalam lembaga pemasyarakatan itu sendiri serta mendukung pembangunan nasional. Penanaman nilai karakter harus ditanamkan sejak dini dalam membentuk pembiasaan diri untuk melaksanakan nilai karakter baik tanpa paksaan dan secara sadar kepada setiap insan manusia dalam penggunaan nilai karakter baik dalam dirinya untuk bersosialisasi dalam kehdiupan bermasyarakat. Sejalan dengan hal tersebut revitalisasi nilai-nilai pancasila kepada warga binaan menjadi sangat penting untuk dilakukan agar para warga binaan mendapatkan arahan serta ilmu pengetahuan yang dapat membimbing mereka kelak setelah bebas dari masa tahanan.

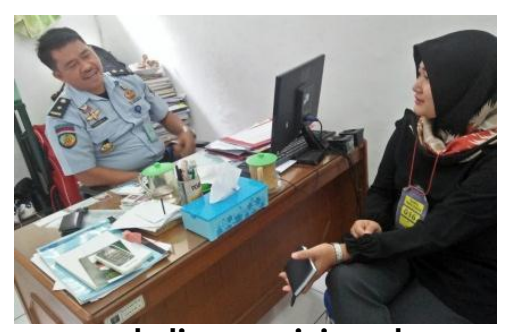

Gambar 4. Wawancara sekaligus perizinan bersama Kasubsi Bimkemaswat 


\section{Tahap Evaluasi}

Evaluasi dalam kegiatan pengabdian pada masyarakat ini perlu adanya pengabdian yang bersifat implementatif yang dapat mengukur adanya tingkat perubahan sikap ataupun perubahan pola tindak para wagra binaan dalam kegiatan pengabdian dimasa mendatang shingga dapat diketahui nilai-nilai pancasila dapat diimplementasikan oleh para warga binaan selama kehidupannya dalam menjalani masa tahanan. Untuk kegiatan pengabdian masyarakat ini tidak mengalami kesulitan ataupun kendala yang ditemui dilapangan baik dalam pelaksanaan kegiatan ataupun perijinan dikarenakan pihak lembaga pemasyarakatan kelas IIA Karawang sangat terbuka dengan adanya kedatangan tim pelaksana pengabdian kepada masyarakat dari Universitas Buana Perjuangan Karawang, dikarenakan menurut pemaparan Kepala Sub Bidang Bimbingan Kemasyarakatan dan Perawatan (Kasubsi Bimkemaswat), sangat diperlukan adanya kegiatan-kegiatan akademik seperti ini untuk dapat mendukung serta mempercepat perwujudan program-program pembinaan yang dimiliki lembaga pemasyarakatan kelas IIA Karawang. Adapaun saran yang ditawarkan agar adanya program berkelanjutan untuk pengabdian pada masyarakat yang sesuai dengan tema untuk dapat ditujukan kepada para warga binaan agar mereka memiliki bekal wawasan dan pengatahuan lebih dalam selama menjalankan masa kehidupan dalam lembaga pemasyarakatan.

Dapat disimpulkan hasil dari kegiatan pengabdian kepada para warga binaan ini, belum dapat dikatakan mampu untuk memberikan perubahan sikap ataupun tingkah laku secara signifikan yang ditunjukan para warga binaan yang berkaitan dengan karakter para warga binaan dikarenakan titik fokus dalam pengabdian ini untuk merevitalisasi (menghidupkan kembali) pengetahuan dan pemahaman para warga binaan mengenai nilai-nilai pancasila sebagai pembentuk nilai karakter warga binaan. Sehingga proses pengimplementasian belum dilaksanakan mengingat pada tujuan utama yaitu untuk menghidupkan kembali, membangkitkan kembali dan mengingatkan kembali nilai-nilai pancasila sebagai guiding principle dalam kehidupan insan manusia indonesia sekalipun mereka akan dikenal dengan sebutan mantan napi tetapi sejatinya para warga binaan tetap sebagai warga negara bangsa Indonesia yang mempunyai kesempatan sama dalam turut serta pembangunan nasional.

\section{PENUTUP}

Kegiatan pengabdian masyarakat secara jelas tersirat bahwa pengetahuan dan pemahaman nilai-nilai Pancasila menjadi kunci utama dalam membentuk karakter para warga binaan pemasyatakatan. Dengan hadirnya sosialisasi mengenai nilai-nilai Pancasila dalam membentuk karakter warga binaan pemasyarakatan sangat dibutuhkan sebab dalam memanusiakan manusia mereka yang butuh sentuhan dan peran pengetahuan yang mendalam untuk memberikan bekal bagi mereka selepas bebas dari tahanan. Hak asasi manusia tetap dilindungi sebagai bagian dari amanat undang-undang, salah satunya hak pendidikan dengan memberikan ruang pengetahuan baru, menghidupkan kembali, mengingatkan kembali menjadi salah satu jalan untuk menjadikan para warga binaan menjadi manusia yang berguna bagi nusa dan bangsa, terkhusus untuk kebutuhan diri mereka selepas keluar dari tahanan agar mempunyai prinsip hidup baik bertanggung jawab untuk dirinya, mampu berperan aktif dimasyarakat dan juga ikut serta dalam pembangunan nasional.

Dapat disimpulkan hasil dari kegiatan pengabdian kepada para warga binaan ini, belum dapat dikatakan mampu untuk memberikan gambaran nyata dalam perubahan sikap ataupun tingkah laku yang ditunjukan para warga binaan secara signifikan yang berkaitan dengan karakter, dikarenakan titik fokus dalam pengabdian ini untuk merevitalisasi (menghidupkan kembali) pengetahuan dan pemahaman para warga 
binaan mengenai nilai-nilai pancasila sebagai pembentuk nilai karakter warga binaan. Sehingga proses pengimplementasian belum dilaksanakan mengingat pada tujuan utama yaitu untuk menghidupkan kembali, membangkitkan kembali dan mengingatkan kembali nilai-nilai pancasila sebagai guiding principle melalui sosialisasi pengabdian dalam kehidupan para warga binaan sebagai insan manusia indonesia, sekalipun mereka nantinya akan dikenal dengan sebutan mantan napi tetapi sejatinya para warga binaan tetap sebagai warga negara bangsa Indonesia yang mempunyai kesempatan sama dalam turut serta pembangunan nasional.

Saran selanjutnya untuk pelaksanaan pengabdian masyarakat kepada para warga binaan, harus dilakukan secara berkelanjutan untuk tahapan pengimplementasian agar dapat terlihat secara jelas perubahan sikap dan pola tindak warga binaan dalam konteks karakter warga binaan dengan nilai-nilai pancasila. Dapat melaksanakan pengabdian dengan teknik ataupun metode yang sesuai dengan tujuan implementasi yang dapat di kolaborasikan dengan penguatan nilai pancasila sebagai pembentuk karaktek warga binaan berbasis program binaan lapas kelas IIA Karawang.

\section{E. UCAPAN TERIMA KASIH}

Saya ucapkan terimakasih kepada LPPM Universitas Buana Perjuangan Karawang, Mahasiswa Program Studi Pendidikan Pancasila dan Kewarganegaraan yang telah senantiasa berkolaborasi dengan baik untuk melaksanakan dan mendukung kegiatan pengabdian kepada masyarakat yang berlokasi di Lapas Kelas IIA Karawang dengan sasaran para warga binaan pemasyarakatan (WBP). Tak lupa saya ucapkan terimakasih kepada mitra kami Lapas kelas IIA Karawang yang telah menerima dan bekerjasama dalam mensukseskan kegiatan pengabdian pada masyarakat ini.

\section{F. DAFTAR PUSTAKA}

Akbal, M. (2016). Pendidikan Kewarganegaraan dalam Pembangunan Karakter Bangsa. Seminar Nasional, 485-493.

Amalia, M. (2017). Journal of empowerment. Journal of Empowermentmpowerment, 1(2), 121-138. https://jurnal.unsur.ac.id/je/article/view/207/127

Atmasasmita, R. (1982). Strategi Pembinaan Pelanggar Hukum Dalam Konteks Penegakan Hukum di Indonesia. Alumni.

Bertens, K. (1983). Filsafat Barat Dalam Abad XX. PT. Gramedia.

Danniarti, R. (2017). Implementasi Nilai-Nilai Pancasila Sebagai Pendukung Tumbuh Kembang Wawasan Kebangsaan Pada Mata Pelajaran Ppkn Di SMP Negeri 7 Palembang. JMKSP Jurnal Manajemen, Kepemimpinan, Dan Supervisi Pendidikan, 1(2), 233-255. The Value of Pancasila, National Insight, PPKn Subject

Fatimah, Zainul Akhyar, F. (2015). Implementasi kebijakan perlindungan hukum terhadap hak-hak narapidana di rutan kelas iib kuala kapuas kal-teng. 5, 672-678.

Hamja. (2014). Model Pembinaan Narapidana Berbasis Masyarakat ( Community Based Corrections ) Dalam Sistem Peradilan. Mimbar Hukum, 27(03), 445-458.

Hamzah, A. \& S. R. (1983). Suatu Tinjauan Ringkas Sistem Pemidanaan di Indonesia. Akademika Presindo. 
Irawan, Y., Rahmalisa, U., \& Aprilia, U. (2019). Sistem Database Pemasyarakatan Studi Kasus Lapas Kelas II A Pekanbaru. Journal of Technopreneurship and Information System (JTIS), 2(2), 59-67. https://doi.org/10.36085/jtis.v2i2.323

Jirzanah. (2016). Aktualisasi Pemahaman Nilai Menurut Max Scheler Bagi Masa Depan Bangsa Indonesia. Jurnal Filsafat, 18(1), 93-114. https://doi.org/10.22146/if.3519

Keputusan Mentri Kehakiman Republik Indonesia No: M.01.PR.07.03 tahun 1985 tentang Organisasi dan Tata Keria Lembaga Pemasyarakatan.

Martini, E. (2018). Membangun Karakter Generasi Muda Melalui Model Pembelajaran Berbasis Kecakapan Abad 21. Jurnal Pancasila Dan Kewarganegaraan, 3(2), $21-$ 27. https://doi.org/10.24269/ipk.v3.n2.2018.pp21-27

Mukhadis, A. (2013). Sosok Manusia Indonesia Unggul Dan Berkarakter Dalam Bidang Teknologi Sebagai Tuntutan Hidup Di Era Globalisasi. Jurnal Pendidikan Karakter, 2, 123499. https://doi.org/10.21831/ipk.v2i2.1434

Octavian, W. A. (2018). Urgensi Memahami dan Mengimplementasikan Nilai-Nilai Pancasila dalam Kehidupan Sehari-Hari Sebagai Sebuah Bangsa. Bhinneka Tunggal lka, 5(2), 123-1 28.

Qiqi Yuliati Zakiyah \& A. Rusdiana. (2014). Pendidikan Nilai. In Sistem Informasi Manajemen. CV. Pustaka Setia.

Rahmatiani, L. (2017). Pembentukan Karakter Siswa Melalui Program Lisa, Libra, Patujar Di SMPN 1 Cilamaya Wetan. CIVICS, 2, 45-55. https://journal.ubpkarawang.ac.id/index.php/PPKn/article/view/266

Rahmatiani, L. (2020). Pendidikan kewarganegaraan sebagai pembentuk karakter bangsa. Prosiding Seminar Nasional Kewarganegaraan, Universitas Ahmad Dahlan, 87-94. http://seminar.vad.ac.id/index.php/snk/article/view/3665

Rahmatiani, L. A. (2020). Role Of Law Protection Of Rights Narapidana In Class IIA Karawang. International Journal of Psychological Rehabilitation, 24(07). https://doi.org/DOI: 10.37200/IJPR/V24I7/PR2700362

Riyanto, A. (2007). Pancasila Dasar Negara Indonesia. Jurnal Hukum \& Pembangunan, 37(3), 457. https://doi.org/10.21143/ihp.vol37.no3.151

Sagala, S. (2009). Konsep dan Makna Pembelajaran untuk Memecahkan Problematika Belajar dan Mengajar. Alfabeta.

Sanjaya, W. (2010). Strategi Pembelajaran Berorientasi Standar Proses Pendidikan. Media Group.

Saputra, F. (2020). Peranan Lembaga Pemasyarakatan dalam Proses Penegakan Hukum Pidana dihubungkan dengan Tujuan Pemidanaan. Jurnal Ilmu Hukum Reusam, VIII(12), 1-15. 
Situmorang, V. H. (2019). Lembaga Pemasyarakatan sebagai Bagian dari Penegakan Hukum. Jurnal Ilmiah Kebijakan Hukum, 13(1), 85. https://doi.org/10.30641/kebijakan.2019.v13.85-98

Sujatno, A. (2008). Pencerahan di Balik Penjara. PT. Mizan Publika.

Undang-Undang No. 39 Tahun 1999 mengenai hak asasi manusia.

Undang-Undang No.12 tahun 1995 tentang Pemasyarakatan.

Wening, S. (2012). Pembentukan Karakter Bangsa Melalui Pendidikan Nilai. Jurnal Pendidikan Karakter, 1(2), 55-66. 